\title{
PENGARUH POROSITAS BUATAN PADA ADSORBER TERHADAP KUALITAS TRANSFER PANAS DAN MASSA
}

\author{
Sukatiman $^{1}$, Dewanto Harjunowibowo ${ }^{2}$ \\ ${ }^{1}$ Program Studi Pendidikan Teknik Bangunan FKIP UNS \\ ${ }^{2}$ Program Studi Pendidikan Fisika FKIP UNS \\ Email: sukatiman@fkip.uns.ac.id
}

\begin{abstract}
On the cooler machine power heat, performance machine efficiency (COP-Coefficient of Performance) is affected by adsorber capacity in adsorbing numbered refrigerant and releasing in fast periode. the velocity will increase if it has velocity transfered heat and high mass.

This research focused on knowing variation effect adsorbed of solid porousity adsorber versus head transfer rate and high mass. Research methods used many relevance references.

The result of this research is that more increasing porousity volume caused high rate of mass transferred and high heat. Yet if to many porousity made volume of adsorber smaller so that mass transferred achieve optimum and decreased.
\end{abstract}

Keywors: power heat, refrigerant, adsorber

\section{PENDAHULUAN}

Sistem pendingin adsorpsi merupakan salah satu dari sistem pendingin yang ramah lingkungan, dimana dalam operasinya sistem ini dapat dibangkitkan menggunakan sumber energi terbarukan seperti biomassa ataupun sinar surya. Perkembangan dari teknologi mesin pendingin tenaga surya mengarah pada teknologi berbasis sistem siklus tertutup dan terbuka yang dipengaruhi oleh panas matahari (Hartmann dkk, 2010).

Menurut Zhai dan Wang (2009) teknologi pendingin tenaga surya didominasi oleh proses absorbsi (Henning, 2007) dan adsorbsi (Li dkk, 2004a). Untuk menjamin kontinuitas operasional pendinginan, pada sistem yang berbasis adsorbsi membutuhkan minimal dua adsorber. Sistem pendingin adsorpsi menggunakan pasangan adsorber dan refrigeran pada sistem kerjanya. Contoh dari adsorber yaitu silika gel dan karbon aktif, sedangkan contoh dari refrigeran yaitu air dan metanol.

Bentuk adsorber yang sering digunakan adalah flat plate (Li dan Sumathy, 2004) dan parabolic evacuated tube, tetapi diantara kedua adsorber tersebut yang paling sering digunakan adalah adsorber yang berbentuk flat plate karena lebih ekonomis, mudah perawatannya dan cukup efisien (Saha dkk., 2001).

JIPTEK, Vol. VII No.2, Juli 2014
Pasangan Karbon aktif dan metanol sudah banyak digunakan dalam penelitian-penelitian terdahulu. Karena suhu akhir yang diperoleh mampu mencapai suhu di bawah $0{ }^{\circ} \mathrm{C}$, meskipun ratio penyerapan efektif terhadap Metanol hanya $0.26 \mathrm{~kg} / \mathrm{kg}$ karbon aktif (Hussein, 2008). Selain itu pasangan adsorber tersebut memiliki coeffisien of performance (COP) yang tinggi dan lebih murah dibandingkan pasangan adsorber lain (Critoph, 1988; Pons dan Guillemiont, 1986).

Keberadaan adsorber dalam sistem mesin pendingin tenaga surya sangat menentukan efisiensi mesin. Oleh karena adsorber ini berfungsi sebagai interface antara mesin dengan sinar matahari. Adsorber yang baik harus mampu menyerap cairan refrigeran sebanyak-banyaknya dan melepaskannya kembali secepatnya dengan bantuan panas matahari. Untuk itu adsorber harus mampu menyebarkan aliran panas yang diterima secara baik dan cepat ke seluruh bagian adsorber.

Kecepatan transfer panas ini berbeda-beda hasilnya antara adsorber berbentuk butiran (granules) dan padatan (solid). Menurut Wang, dkk. (2006), transfer panas pada padatan lebih baik daripada yang butiran. Meski demikian tranfer massa nya rendah. Hal ini dikarenakan kerapatan karbon aktif bentuk padat lebih tinggi daripada bentuk butiran. Selain itu ukuran pori-pori (porousity) dari adsorber juga mempengaruhi laju 
transfer panas dan massa cairan (Kaczmarski dan Bellot, 2003). Jika ukuran pori dari adsorber sesuai dengan ukuran atom dari cairan maka tingkat penyerapannya semakin baik. Sebaliknya jika ukuran pori adsorber terlalu kecil daripada ukuran molekul cairan, maka kemampuan penyerapannya sangat rendah.

Penggunaan Solid Adsorber Pairs yang tepat akan mampu meningkatkan performa dari mesin pendingin (Solar Cooling) sehingga efisiensinya meningkat (COP-Coefficient of Performance). Beberapa penelitian terkait efektifitas Solid Adsorber Pairs telah dilakukan, namun belum ada yang meneliti mengenai pengaruh ukuran diameter pori-pori buatan pada lapisan adsorber serta pengaruh jarak antar poripori terhadap laju transfer panas dan massa cairan refrigeran.

Sehingga dalam makalah ini akan ditelaah secara kepustakaan prinsip kerja secara umum dari Solar Cooling dan keterkaitan antara porositas buatan dengan kemampuan transfer panas dan massa dari sebuah adsorber.

\section{Prinsip Kerja Solar Cooling}

Solar Cooling merupakan sistem pendingin dengan memanfaatkan panas matahari. Mesin tersebut terdiri atas tiga komponen utama (Li dkk,., 2004a), yaitu Generator yang berisi Solid absorbent pair, Kondensor, dan Evaporator penghasil suhu dingin.

Skema Solar Cooling terlihat pada Gambar 1.

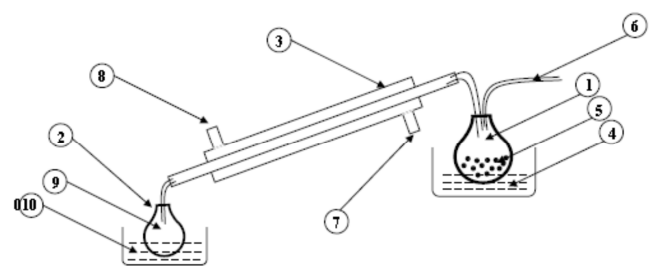

Gambar 1. Skema inti dari Solar cooling. 1. Generator; 2. Evaporator; 3. Kondensor; 4. Oli pemanas; 5. karbon aktif; 6. pipa vakum; $7 \& 8$. inlet \& outlet air kondensor; 9. Metanol; 10. air yang didinginkan.

Alat utama terdiri dari dua ruangan yang saling terhubung dengan salah satu ruang berisi adsorbser (bagian generator) dan ruang yang lain sebagai evaporator. Di dalam generator terdapat padatan yang berfungsi sebagai penyerap cairan bisa berupa pasangan Silika gel-Air (Maggio dkk,.,
2009) atau Karbon Aktif-Metanol ( $\mathrm{Li}$ dan Sumathy, 1999; Li dkk,, 2004b; Dai dkk,. 2002).

Saat siang hari, pada generator terjadi penguapan (desorpsi), uap tersebut menuju kondensor (mengembun) lalu terkumpul di evaporator. Produksi es terjadi saat malam hari $(\mathrm{Li}$ dan Sumathy, 1999; Dieng dan Wang, 2001). Karena tekanan dan suhu di generator lebih rendah dari evaporator, metanol di evaporator mengambil kalor dari lingkungannya untuk menguap menuju adsorber pada Generator (adsorpsi). Karena penyerapan kalor lingkungan oleh Metanol di evaporator, terjadilah es dari air yang berada di lingkungan evaporator.

Menurut Li dan Sumathy (1999), mesin pendingin dengan satu kolektor pelat $\left(0.92 \mathrm{~m}^{2}\right)$, dengan Solid Adsorber Pairs karbon aktif-metanol mampu memproduksi $4.3-5.4 \mathrm{~kg} / \mathrm{m}^{2}$ es per hari dengan COP 0.10-0.12. Hal tersebut senada dengan Li dkk, (2004a), desain SIM tanpa katup menghasilkan es $4.5-7 \mathrm{~kg} / \mathrm{m}^{2}$ perhari dengan COP 0.12-0.14 dan satu kolektor pelat $0.94 \mathrm{~m}^{2}$.

\section{Solid Absorbent Pair}

Proses adsorpsi secara garis besar terbagi menjadi dua jenis yakni adsorpsi secara fisis (Critoph dan Metcalf; 2004) dan kimia (Kato, dkk., 2001). Ikatan van der Walls antara molekul adsorber dengan adsorbat menyebabkan penyerapan secara fisis (Ponec, dkk., 1974). Banyaknya pori yang dimiliki oleh adsorber membuatnya mampu menyerap adsorbat dalam jumlah yang banyak. Penyerapan secara fisis ini akan maksimal jika ukuran pori penyerap sama dengan ukuran molekul cairan yang diserap. Oleh karena itu dilakukan rekayasa pembuatan ukuran pori yang bervariasi sesuai kebutuhan agar diperoleh penyerapan yang maksimal pula. Pembuatan pori-pori tersebut memiliki perlakuan yang berbeda tergantung dari jenis penyerapnya (Zhang, 1989), bisa dengan direaksikan dalam aliran gas atau agen tertentu.

Pembuatan campuran adsorber dilakukan untuk mendapatkan peningkatan pada transfer massa dan panas daripada ketika dalam bentuk aslinya. Jenis adsorber ini biasanya diperoleh dari kombinasi antara adsorber yang dibentuk secara kimiawi dan media pori yang menjadi adsorber secara fisis ataupun tidak. Beberapa contoh dari komposit adsorber tersebut adalah karbon aktif, 
grafit maupun serat karbon (Wang, dkk., 2004; 2006; Aidoun dan Ternan, 2002).

Adsorber yang sering digunakan adalah Karbon aktif (Li dan Sumathy, 1999; Li dkk, 2004b; Dai dkk,. 2002), Serat karbon aktif, zeolit (Wang, dkk., 2009), dan Silika Gel-Air (Yang dalam Li, G dkk., 2012).

Hubungan Porositas terhadap Kemampuan Transfer Panas dan Massa Adsorber

\section{Adsorber}

Adsorber atau kebanyakan zat pengadsorpsi adalah bahan-bahan yang sangat berpori, dan adsorpsi berlangsung terutama pada dinding-dinding pori atau pada daerah tertentu di dalam partikel itu. Karena pori-pori adsorber biasanya sangat kecil maka luas permukaan dalamnya menjadi beberapa kali lebih besar dari permukaan luar. Adsorber yang telah jenuh dapat diregenerasi agar dapat digunakan kembali untuk proses adsorpsi. Suatu adsorber dipandang sebagai suatu adsorber yang baik untuk adsorpsi dilihat dari sisi waktu. Lama operasi terbagi menjadi dua, yaitu waktu penyerapan hingga komposisi diinginkan dan waktu regenerasi/ pengeringan adsorber. Makin cepat dua variabel tersebut, berarti makin baik unjuk kerja adsorber tersebut.

\section{Karakteristik Karbon Aktif sebagai Adsorber}

Karbon aktif biasa dibuat dari material semacam kayu, batubara, tulang, dan kulit kelapa (Wang dkk, 2009). Gambar 2 memperlihatkan struktur dari karbon aktif yang diproduksi dari tulang memiliki cincin enam elemen atom karbon (Zhang, 1989). Kinerja adsorpsi dipengaruhi oleh gugus fungsional yang terhubung ke cincin atom karbon. Sebagai contoh, gugus Arena (gugus aromatis) meningkatkan adsorpsi, sedangkan gugus sulfonat menurunkan daya adsorpsi. Asam gugus fungsional meningkatkan selektivitas adsorpsi. Gugus fungsi pada permukaan karbon aktif berbeda jika bahan asli karbon dan metode aktivasinya berbeda. Area spesifik karbon aktif adalah antara 500 dan $1500 \mathrm{~m}^{2} / \mathrm{g}$.

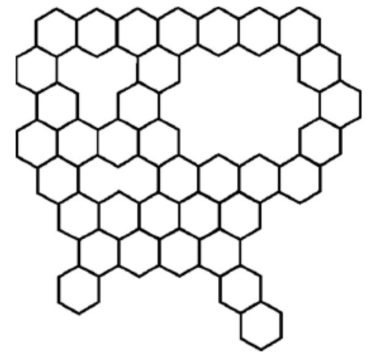

Gambar 2. Struktur atom karbon aktif (Zhang, 1989)

Beberapa hal yang membedakan antara karbon aktif dengan adsorber lain adalah pada bentuk permukaannya. Permukaan karbon aktif, secara keseluruhan, diliputi dengan matrik oksida dan beberapa material anorganik, oleh karena itu karbon aktif bersifat non polar atau hanya memiliki sebuah polaritas yang lemah (Wang dkk, 2009). Penyerapan panas dari pasangan karbon aktif lebih rendah dibandingkan pasangan padatan yang lain.

3. Pengaruh Volume Pori Buatan Adsorber Layer terhadap Transfer Massa dan Panas

Dari Tabel 1 terdapat parameter tentang density atau massa jenis, dan Average thermal conductivity (konduktivitas panas rerata) untuk mengetahui hubungan jarak antar pori adsorber terhadap transfer panas dan massa. Dari data tersebut diketahui bahwa massa jenis karbon aktif yang dipadatkan lebih besar daripada massa jenis karbon aktif dalam bentuk serbuk/butiran.

Tabel 1. Parameter Karbon Aktif

\begin{tabular}{|l|l|l|}
\hline \multicolumn{1}{|c|}{$\begin{array}{c}\text { Physical } \\
\text { properties }\end{array}$} & $\begin{array}{c}\text { Granular } \\
\text { activated } \\
\text { carbon }\end{array}$ & \multicolumn{1}{c|}{$\begin{array}{c}\text { Consolidated } \\
\text { active carbon }\end{array}$} \\
\hline Density & $460 \mathrm{~kg} \mathrm{~m}^{-3}$ & $600 \mathrm{~kg} \mathrm{~m}^{-3}$ \\
\hline $\begin{array}{l}\text { Average } \\
\text { thermal } \\
\text { conductivity }\end{array}$ & $0.11 \mathrm{Wm}^{-1} \mathrm{~K}^{-1}$ & $0.30 \mathrm{Wm}^{-1} \mathrm{~K}^{-1}$ \\
\hline $\begin{array}{l}\text { Specific heat } \\
\text { capacity }\end{array}$ & $\begin{array}{l}0.93 \mathrm{~kJ} \mathrm{~kg}^{-1} \mathrm{~K}^{-} \\
1\end{array}$ & $0.93 \mathrm{~kJ} \mathrm{~kg}^{-1} \mathrm{~K}^{-1}$ \\
\hline
\end{tabular}

(Sumber : Hussein, 2008) 
adalah

Mengingat persamaan massa jenis

$$
\rho=\frac{m}{V}
$$

dimana $\rho$ adalah massa jenis $(\mathrm{kg}$ $\left.\mathrm{m}^{-3}\right), \mathrm{m}$ adalah massa $(\mathrm{kg})$, dan $\mathrm{V}$ adalah volume $\left(\mathrm{m}^{3}\right)$.

Berdasarkan persamaan (1), massa

jenis berbanding lurus dengan massa ( $\rho$ $\approx$ m), jadi massa dari karbon aktif yang dipadatkan lebih besar dari massa karbon aktif dalam bentuk serbuk/butiran. Dengan mengasumsikan volume ruang keduanya adalah sama.

Pemadatan tersebut mengakibatkan jarak antar materi semakin rapat sehingga mengakibatkan panas dari satu titik dapat menginduksi titik-titik lain disekitarnya secara cepat daripada dalam bentuk granul. Hal tersebut mengakibatkan nilai konduktivitas reratanya lebih tinggi dibandingkan dengan granul.

Menurut Sudibandriyo (2011) luas permukaan karbon aktif sebagai adsorber merupakan salah satu parameter yang penting. Karbon aktif dapat dikatakan sebagai adsorber yang baik jika memiliki luas permukaan yang besar. Hal ini karena luas permukaan adsorber merupakan salah satu faktor utama yang mempengaruhi proses adsorpsi. Luas permukaan karbon aktif di pengaruhi oleh struktur pori yang menyusunnya. Dalam penelitiannya, Subandriyo mengemukakan bahwa semakin banyaknya pori-pori yang terbentuk, maka luas permukaan yang dihasilkan juga semakin tinggi.

\section{Pengaruh Volume Pori terhadap Transfer Massa}

Transfer massa yang dimaksud dalam sistem ini merupakan perpindahan zat cair (refrigeran) dari adsorber menuju kondensor yang diwakili oleh satuan debit penguapan. Fungsi adsorber adalah untuk menyerap refrigeran (adsorbate) yang akan diuapkan panas matahari menuju kondensor. Transfer massa ini berhubungan dengan kecepatan adsorpsi karena pada dasarnya pelepasan uap refrigeran ini adalah suatu proses desorpsi.

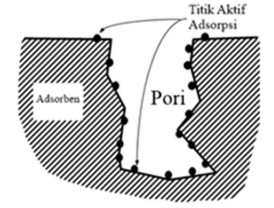

(a)Adsorbent volume pori besar
(1)

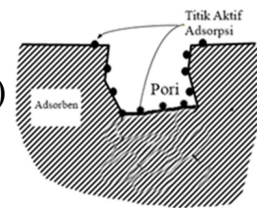

(b) Adsorbent volume pori kecil
Gambar 3. Perbandingan Volume Pori Adsorber dan Titik Aktif Adsorpsinya.

Dari Gambar 3 dapat dilihat semakin besar sebuah pori akan menambah luas permukaan adsorber tersebut, akibatnya titik-titik aktif untuk proses adsorpsi juga semakin banyak akibatnya proses adsorpsi akan semakin cepat dibandingkan adsorber yang memiliki pori yang kecil. Lebih lanjut lagi dapat terlihat pada Gambar 4.
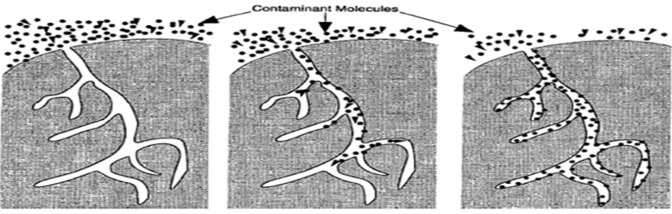

Gambar 4. Proses Terjadinya Adsorpsi Pada Adsorber Berpori (Sumber :

Widy, 2012)

Dari penjelasan di atas dapat disimpulkan bahwa proses adorpsi maupun desorpsi akan semakin maksimal jika menggunakan adsorber yang memiliki pori dengan volume yang besar. Hal ini sesuai dengan pernyataan Suyati dalam Widyastuti, A. Dkk. (2013) bahwa untuk menghasilkan adsorber mikropori yang terbaik, volume total pori dan luas permukaan harus semakin besar namun rerata jari pori semakin kecil. Namun, apabila pemberian pori dilakukan terlalu banyak maka akan membuat rerata jari pori akan semakin besar. Hal ini mengakibatkan 
volume materi adsorber tersebut akan semakin kecil, sehingga massa jenisnya akan mengecil dan volume cairan yang diserap juga mengecil (Gambar 5).

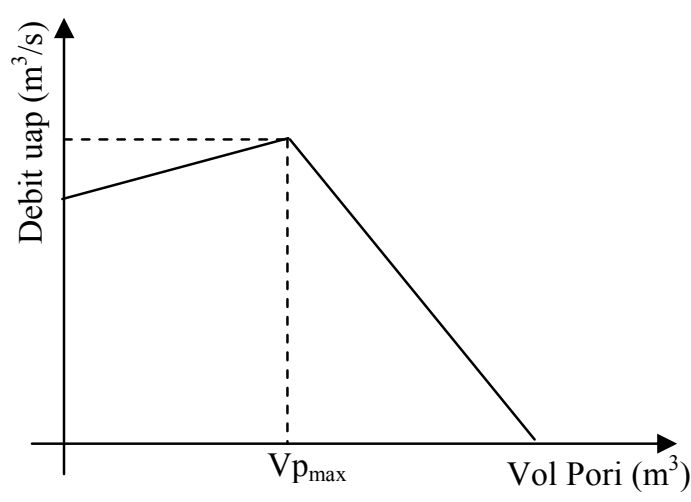

Gambar 5. Grafik titik jenuh karena volume pori yang terus bertambah

Pada Gambar 5 diperlihatkan bahwa saat adsorber padat belum berpori, telah memiliki transfer massa meskipun lebih rendah daripada tipe granul. Dengan penambahan pori buatan maka refrigeran yang menguap namun terjebak dalam adsorber dapat keluar melalui pori-pori tersebut sehingga meningkatkan transfer massanya. Peningkatan transfer massa ini terus terjadi hingga titik maksimal yakni volume refrigeran yang diserap masih cukup banyak dan jumlah poriporinya optimal. Selanjutnya, pada setiap penambahan pori-pori buatan mengakibatkan massa adsorber terus menurun, volume refrigeran yang terserap menurun sehingga debit penguapan juga mengalami penurunan. Penurunan transfer massa ini terus terjadi hingga volume pori-pori total sama dengan volume adsorber yang artinya tidak terdapat lagi adsorber sehingga tidak ada air yang diserap dan tidak ada penguapan.

Oleh karena itu, dalam pemberian pori pada adsorber harus ada batas maksimalnya. Apabila melampaui batas ini maka proses desorpsi/transfer massa tidak lagi berjalan dengan baik. Dengan demikian dapat diasumsikan bahwa volume pori adsorber akan memiliki titik jenuh. Gambar 6 adalah ilustrasi adsorber yang telah mencapai titik jenuhnya yang terus dilakukan pemberian pori lebih banyak lagi.
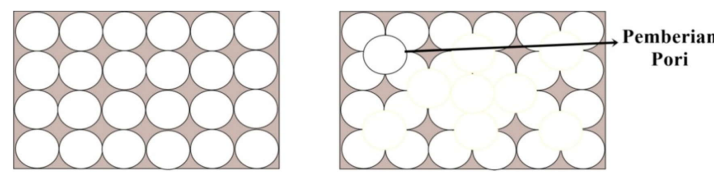

Gambar 6. Pemberian Pori

Tambahan pada Adsorber yang Telah Melewati Titik Jenuhnya

Apabila pemberian pori dilakukan melewati batas maksimal titik jenuhnya maka titik aktif adsorpsi akan semakin berkurang. Hal ini karena pori-pori mengurangi massa adsorber tersebut.

\section{Pengaruh Volume Pori terhadap Transfer Panas}

Transfer panas adalah perpindahan energi karena adanya perbedaan temperatur. Ada tiga bentuk mekanisme perpindahan panas yang diketahui, yaitu konduksi, konveksi, dan radiasi. Transfer panas dalam sistem ini merupakan perpindahan panas dari panas matahari ke adsorber untuk menguapkan refrigeran.

Kecepatan transfer panas ini berbeda-beda hasilnya antara adsorber berbentuk butiran (granules) dan padatan (solid). Menurut Wang, dkk. (2006), transfer panas pada padatan lebih baik daripada yang butiran. . Pada karbon aktif yang dipadatkan, jarak antar molekulnya rapat, hal ini memungkinkan transfer panas ke adsorber lebih cepat.

Sebaliknya, untuk adsorber karbon aktif dalam bentuk butiran mempunyai transfer panas yang lebih rendah karena jarak antar molekul penyusunnya renggang mengakibatkan panas dari matahari akan lama mengkonduksi molekul tetangganya. Akibatnya panas yang diterima adsorber akan lebih lama untuk menguapkan refrigeran. Dengan demikian transfer panas adsorber dalam bentuk padatan lebih baik daripada bentuk butiran.

Analisis yang telah dikemukakan dapat diperjelas dengan persamaan (2) sebagai berikut:

$$
\frac{Q}{t}=k A \frac{\Delta T}{l}
$$


Dimana,

$\frac{Q}{t}=\operatorname{Laju}$ kalor $(\mathrm{J} / \mathrm{s})$

${ }^{1} \mathrm{~K}^{-1}$ )

$\mathrm{k}=$ Konduktivitas termal $(\mathrm{Wm}$

$\mathrm{A}=$ Luas Penampang $\left(\mathrm{m}^{2}\right)$

$\Delta \mathrm{T}=$ Selisih kenaikan suhu $(\mathrm{K})$

1 = Panjang penghantar $(\mathrm{m})$

Berdasarkan persamaan (2) dapat

disimpulkan bahwa semakin besar

konduktivitas termal suatu bahan, maka laju panas juga akan semakin besar. Pada Tabel 1 diketahui bahwa konduktivitas termal karbon aktif yang dipadatkan lebih besar daripada karbon aktif yang berbentuk butiran, dengan demikian laju panas karbon aktif yang dipadatkan akan lebih besar daripada karbon aktif bentuk butiran, maka transfer panas adsorber karbon aktif yang dipadatkan lebih baik daripada adsorber bentuk butiran.

Menurut Hidayat menyatakan bahwa nilai konduktifitas termal akan berubah bila berat jenisnya berubah. Semakin tinggi berat jenis maka semakin baik pengalir konduktifitas tersebut.

$$
\gamma=\frac{m \cdot g}{V}
$$

Dimana,

$$
\begin{aligned}
& \gamma: \text { berat jenis }\left(\mathrm{kg} / \mathrm{m}^{3}\right) \\
& \mathrm{m}: \text { massa }(\mathrm{kg}) \\
& \mathrm{g}: \operatorname{gravitasi}\left(\mathrm{m} / \mathrm{s}^{2}\right) \\
& \mathrm{v}: \operatorname{volume}\left(\mathrm{m}^{3}\right)
\end{aligned}
$$

Sesuai dengan persamaan (3), apabila adsorber berpori dengan volume total yang luas maka massa adsorber itu sendiri menjadi lebih sedikit sehingga berat jenisnya akan semakin kecil, sehingga konduktivitas termalnya semakin kecil juga. Dengan kata lain, tranfer panas akan lebih maksimal terjadi pada adsorber yang memiliki sedikit pori atau volume total pori yang kecil.

Dapat disimpulkan bahwa pemberian pori pada adsorber ini sangat mempengaruhi proses desorpsi pada sistem solar cooling. Maka dari itu untuk mendapatkan performa adsorber yang maksimal hendaknya memperhatikan kualitas adsorber tersebut. Namun pada kepadatan yang sama, pembuatan pori tidak akan mempengaruhi transfer panas bahkan justru meningkatkan. Hal ini karena panas dapat masuk ke pori dan menginduksi materi tetangganya sehingga penyebaran panas dalam bahan menjadi lebih cepat.

\section{METODE PENELITIAN}

single layer adsorber dari bahan karbon aktif. Bahan karbon aktif dalam penelitian ini menggunakan karbon aktif tempurung kelapa yang dijual bebas di pasaran buatan Bratachem. Variasi diameter pori-pori pada lempeng adsorber ini bervariasi dari 5 $\mathrm{mm}, 6 \mathrm{~mm}, \quad 7 \mathrm{~mm}, 8 \mathrm{~mm}, 9 \mathrm{~mm}$, dan $10 \mathrm{~mm}$. Jarak antar pori-pori adalah $20 \mathrm{~mm}$ dan luas total adalah $1 \mathrm{~m} 2$ dengan tebal lempeng $4 \mathrm{~cm}$ dan berat $20 \mathrm{~kg}$. Dari lempeng adsorber ini kemudian dipasang pada single adsorbent bed (generator tunggal) terbuat dari bahan stainless steel dan ditutup fiber glass transparan (Gambar 5). Bahan stainless steel grade 304-304L digunakan karena memiliki spesifikasi yang dibutuhkan yakni tahan panas hingga $500^{\circ} \mathrm{C}$ dan tahan korosi akibat dari bahan adsorbent pair yang digunakan bersifat korosif. Selain variasi diameter pori-pori, penelitian ini juga mencari pengar(w) jarak antar pori-pori pada adsorber terhadap transfer massa dan panas. Jarak antar pori-pori ini bervariasi dari $10 \mathrm{~mm}, 20$ $\mathrm{mm}, 30 \mathrm{~mm}, 40 \mathrm{~mm}$, dan $50 \mathrm{~mm}$. Metode pengujian terpenting adalah pada kinerja unit generator yang didalamnya terdapat solid adsorbent pair yang akan diteliti karakteristik sistemnya.Pengujian ini meliputi ketahanan terhadap keadaan vakum dan ketahanan terhadap panas.

\section{HASIL}

Sesuai dengan rencana pelaksanaan penelitian, kegiatan-kegiatan yang dilakukan dibantu oleh berbagai pihak yang berkompeten. Beberapa hasil yang telah dicapai bersama tim mahasiswa sebagai salah satu komponen pelaksana dalam penelitian ini adalah perancangan dan pembangunan alat uji mesin pendingin tenaga panas telah terlaksana hingga 90\% (Gambar 7). Bagian yang masih harus diselesaikan adalah pengujian alat terhadap kebocoran dan tekanan. 


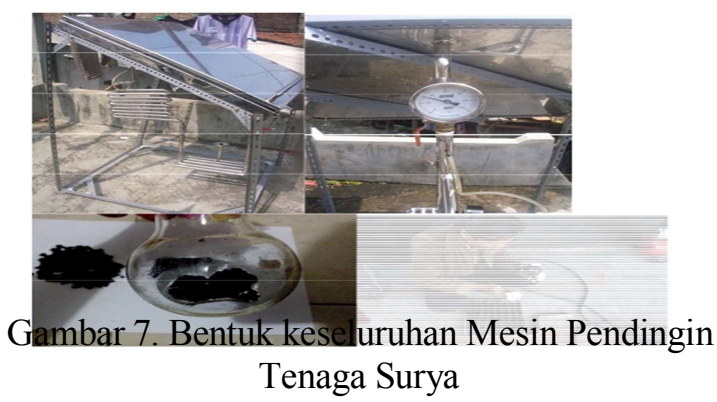

Tahapan selanjutnya adalah pembuatan adsorber yang berupa karbon aktif yang dipadatkan ( Gambar 8). Tujuan utama dari pemadatan ini adalah guna mendapatkan kerapatan adsorber yang lebih besar dan sesuai dengan tujuan dari penelitian ini. Yakni ingin menyelesaikan permasalahan transfer massa pada padatan yang kecil dibandingkan dalam bentuk serbuk ataupun granul.

Pembuatan karbon aktif padatan dari bentuk serbuk ataupun granul tidak dapat dilakukan sembarangan. Mengingat pemadatan membutuhkan ikatan yang cukup kuat dan harus tahan panas. Oleh karena itu pemadatan dengan cara dilakukan pengepressan/penekanan tidak akan berhasil baik sehingga diperlukan pengikat. Pengikat inipun juga harus memiliki kriteria tahan panas, fleksibel meskipun dipanaskan, dan tidak larut dalam larutan organic (methanol).

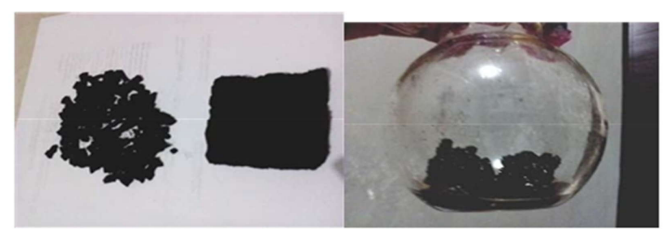

Gambar 8. Bentuk karbon berturutan granul, padatan dan kelarutan dalam methanol

Pembuatan karbon padatan ini selanjutnya dilakukan pengeboran dengan ukuran diameter 1 $\mathrm{cm}$ pada adsorber dengan variasi jarak antar pori 1 , 2, 3, 4, dan $5 \mathrm{~cm}$, sehingga diperlukan lembaran padatan sebanyak 5 sampel. Variasi berikutnya adalah pembuatan padatan lagi dengan jumlah 5 sampel variasi besar diameter namun jarak antar pori yang tetap sesuai dengan hasil dari variasi antar pori. Variasi diameter pori adalah $5,6,7,8,9,10 \mathrm{~mm}$ namun jika pada pelaksanaannya mengalami kesulitan mendapatkan diameter yang akurat maka diameter lubang pori dapat diubah menjadi 5, 7, 9, 11, $13 \mathrm{~mm}$.

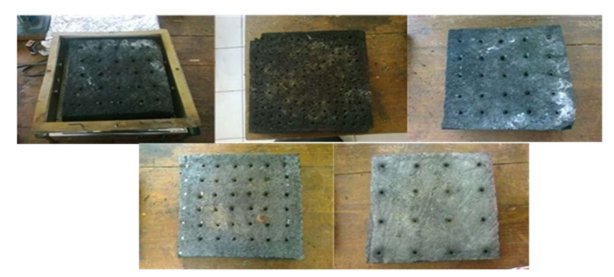

Gambar 9. Karbon aktif terpadatkan

Komposisi bahan Pembuatan karbon aktif terpadatkan berhasil diperoleh bentuk yang bagus Dengan komposisi Pva, Karbon aktif dan aquades Berturut-turut Adalah 80gr , 1,2 kg dan 750ml.

\section{PEMBAHASAN}

Tahapan yang akan dilakukan adalah melakukan pengujian mesin pendingin tenaga surya yang telah dibuat. Pengujian ini meliputi pengujian tekanan udara system dan uji daya tahan panas. Kedua unsur pengujian ini penting dilakukan karena system ini berlangsung secara tertutup. Dengan kata lain tidak diperbolehkan berinteraksi dengan lingkungan luar system.

Pengujian daya tahan panas berfungsi untuk memastikan bahwa alat terutama pada bagian generator mampu berfungsi normal pada kisaran suhu maksimal $150{ }^{\circ} \mathrm{C}$. Dengan ketahanan ini maka alat akan dapat digunakan pada bahan refrigerant jenis lain yang membutuhkan panas tinggi semisal air murni yang mendidih pada suhu $100^{\circ} \mathrm{C}$. Pengujian akan dilakukan di Bengkel Fisika FKIP karena memiliki alat pengukur vakum dan manometer untuk mengukur tekanan hingga 2 atm. Demikian pula Bengkel Fisika memiliki kompor pemanas hingga $300{ }^{\circ} \mathrm{C}$ untuk melakukan pemanasan pada generator.

$$
\text { Alat Solar Cooling masih dalam }
$$
perbaikan sehingga belum dapat diujicoba 
tekanan udara. masih terdapat kebocoran halus yang terdeteksi ada pada sambungan alat pressure gauge.

Sementara itu, pembuatan adsorber berupa karbon aktif yang dipadatkantelah dilakukan di Lab Kimia Dasar di PMIPA FKIP. Sekaligus pengujian dan pengeringan adsorber akan dilakukan menggunakan oven di Lab Kimia Dasar tersebut. Selanjutnya pengeboran pori dilakukan di Bengkel Fisika.

Gambar 9 , menunjukkan keberhasilan yang Penting mengingat karbon aktif terpadatkan tidak lengket pada cetakan dan pulen. Pembuatan karbon aktif terpadatkan ini dilakukan 10 buah, masingmasing dilakukan variasi diameter lubang dan variasi jarak antar pori . Rencana pengujian adsorber akan menggunakan alat distilasi dengan beberapa modifikasi pada generatornya. Pengambilan data juga diperkirakan dapat dilakukan sekaligus di Lab Kimia tersebut. Dari hasil analisis data yang diperoleh maka akan didapatkan struktur adsorber paling optimal untuk diaplikasikan ke Mesin Pendingin Tenaga Surya. Pengujian ini mengalami kendala pada seal anti bocor pada alat heat transfer yang tidak rapat sehingga perlu dilakukan perbaikan segera.

Terakhir adalah tahap pelaporan yang berisi hasil penelitian dan analisisnya berserta pembuatan artikel ilmiah. Direncanakan artikel ilmiah ini diseminarkan pada seminar internasional serta jurnal nasional.

\section{KESIMPULAN DAN SARAN}

Beberapa kesimpulan yang dapat diambil dari kemajuan penelitian ini adalah :

1. Rancang bangun mesin pendingin tenaga surya telah selesai $90 \%$.

2. Pembuatan karbon aktif dipadatkan memerlukan senyawa kimia tertentu sebagai perekatnya dengan komposisi tertentu.

Beberapa saran yang dapat dilakukan untuk penyempurnaan penelitian ini adalah :

1.Perlunya menggunakan perekat karbon aktif yang lebih murah namun memenuhi criteria tahan panas, tidak menghambat penyerapan methanol dan ramah lingkungan.

2.Pengujian harus dilakukan baik pada mesin pendingin tenaga surya ataupun pada adsorber dalam skala lab.

\section{KESIMPULAN}

Prinsip dasar dari teknologi solar cooling adalah peristiwa evaporasi pada kulit yang berkeringat karena kepanasan. Keringat menyerap panas tubuh kemudian menguap sehingga suhu tubuh menurun. Semakin besar volume pori-pori buatan pada adsorber, maka semakin besar transfer panas dan massanya. Namun pada suatu ketika, transfer massa menjadi jenuh dan menurun karena volume adsorber makin berkurang.

\section{DAFTAR PUSTAKA}

Aidoun Z, dan Ternan M. 2002. Salt impregnated carbon fibres as the reactive medium in a chemical heat pump: the NH3-CoCl2 system. Appl Therm Eng;22:1163-73.

Critoph RE, Metcalf SJ. 2004. Specific cooling power intensification limits in ammonia-carbon adsorption refrigeration systems. Appl Therm Eng;24(5-6):661-78.

Critoph, R.E. 1988. Performance limitations of adsorption cycles for solar cooling, Solar Energy $41 ; 21-$ 31.

Dai Y.J., R.Z. Wang, Y.X. Xu. 2002. Study of a solar powered solid adsorption-desiccant cooling system used for grain storage. Renewable Energy 25. hal 417-430.

Dieng A.O., dan Wang R.Z., 2001. Literature review on solar adsorption technologies for icemaking and air-conditioning purposes and recent developments in solar technology, Renewable \& Sustainable Energy Reviews 5 (4) hal. 313-342.

Hartmann, N., Glueck, C., Schmidt, F.P., 2011. Solar cooling for small office buildings: Comparison of solar thermal and photovoltaic options for two different European climates. Renewable Energy 36. pg. 1329-1338. 
Henning H-M. 2007. Solar assisted air conditioning of buildings - an overview. Applied Thermal Engineering;27:1734-49

Hidayat, Syarif. 2011. Sifat Thermal Bahan. Jakarta : Pusat Pengembangan Bahan Ajar Universitas Mercubuana

Hussein, W.K.S., 2008. Solar Energy Refrigeration by Liquid-Solid Adsorption Technique, Master Thesis, An-Najah University, Palestine.

Kaczmarski, K. dan Bellot, J. Ch., 2003. Effect Of Particle-Size Distribution and Particle Porosity Changes on Mass-Transfer Kinetics. Acta Chromatographica, No. 13.

Kato Y, Yamada M, Kanie T, Yoshizawa Y. 2001. Calcium oxide/carbon dioxide reactivity in a packed bed reactor of a chemical heat pump for high-temperature gas reactors. Nucl Eng Des;210:1-8.

Li Z.F., dan Sumathy, K. 1999. A solar powered ice-maker with the solid adsorption pair of activated carbon and methanol, International Journal of Energy Research 23 (6) ; 517-527.

Li, G., Hwang, Y., Radermacher, R., 2012. Review of cold storage materials for air conditioning application, International Journal of Refrigeration, doi: 10.1016/j.ijrefrig.2012.06.003.

Li, M, Huang, H.B., Wang, R.Z., Wang, L.L., Cai, W.D., Yang, W.M. 2004b. Experimental study on adsorber of activated carbon with refrigerant of methanol and ethanol for Solar Ice Maker. Renewable Energy 29. hal 2235-2244.

Li, M, Sun, C.J., Wang,R.Z. dan Cai, W.D. 2004a. Development of no valve Solar Ice Maker. Applied Thermal Engineering 24. hal 865-872.

Maggio G, L.G. Gordeeva, A. Freni, Yu.I. Aristov, G. Santori, F. Polonara, G. Restuccia. 2009. Simulation of a solid sorption ice-maker based on the novel composite sorbent "lithium chloride in silica gel pores". Applied Thermal Engineering 29 hal. 1714-1720.

Ponec V, Knor Z, Cerny S. 1974. Adsorption on solids. London, England: Butterworth Group;

Pons, M. dan Guillemiont, J.J. 1986. Design of an experimental solar-powered, solid-adsorption ice maker, Trans. ASME, J. Solar Energy Eng. 108 (4) ; 332-337.

Saha BB, Akisawa A, Kashiwagi T. 2001. Solar/waste heat driven two-stage adsorption chiller: the prototype. Renew Energy;23(1):93-101.

Sudibandriyo. M, Lydia. 2011. Karakteristik Luas Permukaan Karbon Aktif Dari Ampas Tebu dengan Aktivasi Kimia. Jakarta : Universitas Indonesia.

Wang K, Wu JY, Wang RZ,Wang LW. 2006. Effective thermal conductivity of expanded graphite-CaCl2 composite adsorber for chemical adsorption chillers. Energy Convers Manage;47(13-14):190212.

Wang LW, Wang RZ, Wu JY, Wang K. 2004. Compound adsorber for adsorption ice maker on fishing boats. Int J Refrig;27:401-8.

Wang, L.W., Wang, R.Z., Oliveira, R.G., 2009. A review on adsorption working pairs for refrigeration. Renewable and Sustainable Energy Reviews. 13(3), 518-534.

Widy, Stefano. 2012. Faktor yang Mempengaruhi Adsorpsi Hidrogen pada Karbon Aktif. http://fannowidy.blogspot.com/2012/03/faktor-yang-mempengaruhi-adsorpsi.html. Diakses pada tanggal 5 Juni 2013.

Widyastuti, A., Sitorus, B., Jayuska, A., 2013. Karbon Aktif Dari Limbah Cangkang Sawit Sebagai Adsorben Gas Dalam Biogas Hasil Fermentasi Anaerobik Sampah Organik. JKK, tahun 2013, volume 2 (1), halaman 30-33.

Zhai, X.Q., dan Wang, R.Z., 2009. A review for absorbtion and adsorbtion solar cooling systems in China. Renewable and Sustainable Energy Reviews 13 hal 1523-1531

Zhang YH. 1989. Adsorption function. Shanghai, China: Publishing House of Scientific and Technological Literature in Shanghai. 